\title{
ISOLATION AND CHARACTERIZATION OF HIGH AMBIENT ELECTROMAGNETIC RADIATION (EMR) BACTERIA
}

\author{
NOOR AFIZA BADALUDDIN ${ }^{1}$, SEET YONG YIN ${ }^{1}$, ROSLAN UMAR ${ }^{2 *}$, NOR HAZMIN SABRI ${ }^{3}$, \\ NURUL SYAFIQAH HASSHIM², MOHAMMAD KHAIRUDDIN ALI ${ }^{2,4}$ \\ and A. RASHAD MOHAMED ${ }^{4}$
}

${ }^{1}$ School of Agriculture Science \& Biotechnology, Universiti Sultan Zainal Abidin, Besut Campus, 22000 Besut, Terengganu, Malaysia

${ }^{2}$ East Coast Environmental Research Institute, Universiti Sultan Zainal Abidin, Gong Badak Campus, 21300 Kuala Nerus, Terengganu, Malaysia

${ }^{3}$ Faculty of Science and Marine Environment, Universiti Malaysia Terengganu, 21030 Kuala Nerus, Terengganu, Malaysia

${ }^{4}$ DNZ Teknik Enterprise, $796 \mathrm{Kg}$ Kubang Birai, Jalan Kubang Panjang

21400 Kuala Terengganu, Terengganu, Malaysia

*E-mail: roslan@unisza.edu.my

Accepted 8 December 2020, Published online 25 December 2020

\begin{abstract}
Low-frequency electromagnetic radiation (EMR) exists in our environment and remain unnoticeable. Studies show that EMR exposure may affect human health, animal, plants, and also living microorganisms. Therefore, this study intended to isolate, identify, and characterize bacteria exposed to high ambient EMR as well as to determine the viability and mutagenicity of bacteria exposed to different frequencies. The bacterial samples were collected from two areas with high and low electric field strengths; Universiti Malaysia Terengganu (UMT) hostel $(0.14 \mathrm{~V} / \mathrm{M}$ ) and near Lake of UniSZA (Universiti Sultan Zainal Abidin) $(0.03 \mathrm{~V} / \mathrm{M})$. The bacteria were identified and characterized by several methods. The viability and mutagenicity of each bacterial species were determined by counting the number of colonies formed in the enriched (standard) and minimal media after exposure of $10 \mathrm{MHz}$ and $5 \mathrm{GHz}$ frequencies. The results show that Enterobacter sp., which was isolated in UMT hostel, exhibited non-mutagenic and increased viability after $24 \mathrm{hr}$ of exposure to both EMR frequencies of $10 \mathrm{MHz}$ and $5 \mathrm{GHz}$. Thus, this bacterial species should be further studied since it has the potential as a bioremediator.
\end{abstract}

Key words: Electromagnetic Radiation (EMR), bacteria, Non-Ionizing Radiation (NIR), mutagenicity, bioremediator

\section{INTRODUCTION}

Contemporary society is exposed to a high-tech lifestyle every day. For example, mobile phone usage in this era of globalization is a significant part of everyday life as well as a communication tool for all ages. The use of mobile phones, however, has long-term adverse effects on our daily lives due to the emission of electromagnetic radiation (EMR). The radiation emitted by electric and electronic equipment including industrial machines, gadgets, wireless communication is known as non-ionizing radiation (NIR), refers to a type of radiation that

* To whom correspondence should be addressed. does not have enough quantum energy for ionization (Syaza et al., 2017).

Although NIR can penetrate the human body with no enough energy to ionize atom molecule, however, long time exposure of it can give harm to the human body as its exposure was one of the important factors for an electromagnetic field (EMF) to react with the human body (Hidisoglu et al., 2016). Long-term exposure to NIR may affect human health, which manifests through headaches, insomnia, miscarriage, cancer, and as well as damage to the reproductive system (Cmara, 2014; Bahaodini et al., 2015).

According to a previous study, the application of electromagnetic pulses had inactivated and caused a lethal effect on E. coli suspended in a 
buffer solution (Li et al., 2004). Also, Mohamed et al. (1997) reported that exposure of the microorganism to a magnetic field had caused changes to growth characteristics and increased the number of cells at the stationary phase. High-frequency EMR effect is crucial for understanding the role and differentiation of bacteria in the biosphere that leads to a changing of the metabolic pathway, for example, antibiotic resistance (Tedevosyan et al., 2008). Cam et al. (2014) found that when the specific absorption rate (SAR) value was less than the limit set by the International Non-ionizing Radiation Protection Commission (ICNRIP), evidence showed that Global System for Mobile Communications (GSM) signals alter the hydroxyproline concentration on the skin of mice. Therefore, this study aimed to understand the biological effect of bacteria upon EMR exposure.

This study collected bacterial samples exposed to high ambient EMR to isolate, identify, and characterize each isolated bacterium. The effects of radiation on bacteria were observed by determining the viability and mutagenicity of each isolated bacterium after exposure to different EMR frequencies. Bacteria that exhibit resistance to EMR have the potential as a bioremediator to reduce non-ionizing radiation and thus, decrease the potential of biological harm.

\section{MATERIALS AND METHODS}

\section{Isolation of bacteria}

Bacterial samples were collected from soil and surfaces near the Lake of Universiti Sultan Zainal Abidin (UniSZA), (5²4' 24.066" N, $103^{\circ} 5^{\prime} 2.1732^{\prime \prime}$ E) and hostel area in Universiti Malaysia Terengganu (UMT), (5²4' 19.0044" N, 103 5' 39.8904" E) where both sites are located at Gong Badak, Terengganu. The sampling sites were selected based on the previous study done by Syafiqah et al. (2018) which found that the base station tower is the most influential factor of the reading of ambient NIR exposure level. The distance of the transmitter to the Lake of UniSZA, Gong Badak, and UMT hostel was approximately $200 \mathrm{~m}$ and $10 \mathrm{~m}$ respectively. While sampling collection is conducted, the value of exposure in terms of the electric field (EF) was recorded using Keysight Spectrum Analyser and analyzed using the same method used in the study done by Hasshim et al. (2019) and Rosley et al. (2019). The strength of the electric field around the Lake of UniSZA, was $0.03 \mathrm{~V} / \mathrm{M}$, whereas in UMT hostel was $0.14 \mathrm{~V} / \mathrm{M}$. Bacteria from soil samples were isolated by dissolving $1 \mathrm{~g}$ of soil sample with $9 \mathrm{~mL}$ of $0.9 \%$ sterilized saline water in a falcon tube and the mixtures were mixed homogenized with a vortex mixer. Then, the soil solution was streaked onto Nutrient Agar (NA) plate. While the cotton swab which consisted of bacteria samples from surfaces of the sampling sites was swabbed evenly on the NA plate for bacteria isolation. All the NA plates were incubated in an incubator at $37^{\circ} \mathrm{C}$ aerobically for 16-24 hr. The bacterial were subcultured to obtain a pure culture.

\section{Phenotypic identification of bacteria}

Various biochemical tests were carried out on each isolated bacterium, such as amylase test, catalase test, oxidase test, triple sugar iron test, and sulfide-indole-motility (SIM) test. Each bacterium was classified primarily through morphological, physiological, and biochemical observations to confirm bacterial identification.

\section{Amylase test}

Amylase production had been analyzed by streaking the bacteria colony as a single line on a starch agar plate and incubated at $37^{\circ} \mathrm{C}$ for $48 \mathrm{hr}$. After incubation, iodine solution was flooded on the surface of plates for 30 secs and the results were observed (Bharat, 2013). Amylase production was detected as a colorless zone on the surrounding colony on the addition of iodine (Mendpara et al., 2013).

\section{Catalase test}

Catalase had been done by taken a drop with $3 \%$ of hydrogen peroxide solution on a clean slide and transferred bacterial colonies into it. A positive result was detected by the formation of air bubbles (Hemraj et al., 2013).

\section{Oxidase test}

Oxidase test had been carried out to test the presence of cytochrome $\mathrm{C}$ of isolated bacteria. A drop of $1 \%$ oxidase reagent was placed on filter paper. Then, one or two colonies were transferred by using a wire loop onto soaked filter paper. The positive test was indicated by the development of purple color in 5-10 secs (Hemraj et al., 2013).

\section{Triple sugar iron (TSI) test}

The bacterial culture was stabbed by using a wire needle into the middle of TSI agar and the microbial culture had been streaked gently onto the surface of the agar slant. The tubes were incubated for $24 \mathrm{hr}$ at $37^{\circ} \mathrm{C}$. The slant color, production of gas, and $\mathrm{H}_{2} \mathrm{~S}$ production were observed.

\section{Sulfide-indole-motility (SIM) medium}

According to Hemraj et al., 2013, the SIM test was done by stabbing the isolated colony into SIM agar by wire needle and then incubated at $37^{\circ} \mathrm{C}$ for 
24 to 48 hr. Five drops of Kovacs reagent had been added to the top to test the presence of indole, a byproduct of tryptophan metabolism. A positive indole test was indicated by the formation of red color in the reagent layer within seconds of adding the reagent. If a culture was indole negative, the reagent layer remains yellow or be slightly cloudy.

\section{Molecular identification of bacteria}

Genomic DNA of the isolated bacteria was extracted following the instructions on the Wizard ${ }^{\circledR}$ Genomic DNA Purification Kit. Then, PCR was carried out by using primer pairs targeting the bacterial 16S rRNA gene, which included 16SF2 (5'- GAG TTT GAT CCT GGC TCA -3') for the forward primer and 16SR2 (5'- ACG GCT AAC TTG TTA CGA -3') for the reverse primer with exTEN 2X PCR Master Mix (First Base, USA). PCR amplification was conducted as follows: initial denaturation step at $95^{\circ} \mathrm{C}$ for 2 mins followed by 30 cycles of denaturation at $95^{\circ} \mathrm{C}$ for $30 \mathrm{secs}$, annealing temperature at $50^{\circ} \mathrm{C}$ for $1 \mathrm{~min}$, extension at $72^{\circ} \mathrm{C}$ for 2 mins, and a final extension at $72^{\circ} \mathrm{C}$ for 10 mins. The PCR sequence was compared with the databases in the National Centre for Biotechnology Information (NCBI).

\section{Experimental tests for abiotic factors}

Abiotic factors are the non-living factors in an environment such as temperature, salinity, and $\mathrm{pH}$ that affected the organisms. These experimental tests were carried out to determine the characteristics of the isolated bacteria (Pepper et al., 2015).

\section{Salinity test}

Each isolated bacterium was grown on a NA media plate containing $2.5 \%, 5.0 \%, 7.5 \%$ and $10 \%$ of $\mathrm{NaCl}$. A control NA plate had no addition of $\mathrm{NaCl}$. A loopful of fresh bacterial culture (OD approximately 0.5 at $600 \mathrm{~nm}$ ) was streaked as a single line on each NA media plate containing different concentrations of $\mathrm{NaCl}$ and incubated for 24-36 h. The salt-tolerant isolated bacteria were determined by observing the bacterial growth on NA media plates with different percentages of salt.

\section{Growth temperature test}

A loopful of isolated bacteria from a fresh culture $\left(\mathrm{OD}_{600}=\sim 0.5\right)$ was streaked as a single line on NA media plates. Then, each NA plate was incubated at different temperatures, $10^{\circ} \mathrm{C}, 25^{\circ} \mathrm{C}$, $30^{\circ} \mathrm{C}, 37^{\circ} \mathrm{C}, 45^{\circ} \mathrm{C}, 50^{\circ} \mathrm{C}$, and $60^{\circ} \mathrm{C}$ and incubated for 24-36 hr. The optimum temperature for each bacterial growth was determined.

\footnotetext{
pH test

A loopful of isolated bacteria from fresh culture $\left(\mathrm{OD}_{600}=\sim 0.5\right)$ was streaked as a single line on NA
}

media plates with different $\mathrm{pH}$ ranging from 4.0 to 9.0 and incubated for 24-36 hr. The optimum $\mathrm{pH}$ for each bacterial growth was determined.

\section{EMR exposure test}

The isolated bacteria were inoculated into Luria broth (LB) and allowed to grow overnight in an incubator shaker at $37^{\circ} \mathrm{C}$. The bacterial suspension was then diluted in a fresh medium and cultured to a density of $10^{6}$ cells per $\mathrm{mL}$. Then, $10 \mathrm{~mL}$ of this suspension was transferred into falcon tubes and ready for EMR exposure for $24 \mathrm{hr}$. The exposure system was developed for two different exposure conditions at $10 \mathrm{MHz}$ and $5 \mathrm{GHz}$ using the DDS VFO Signal Generator. The treated samples were kept in a dark box and a temperature-controlled environment. Simultaneous tests were constantly performed with non-exposed controls in falcon tubes identical to those used for treated samples (Salmen et al., 2018).

\section{Determining the viability of the bacteria}

The viability of bacteria was determined after $24 \mathrm{hr}$ of EMR exposure (10 MHz and $5 \mathrm{GHz}$ ). The exposed samples were diluted in peptone water through the serial dilution process and $0.1 \mathrm{~mL}$ of each diluted sample was plated on nutrient agar. Each treatment was replicated to ensure the accuracy of the data. The colonies forming units per $\mathrm{mL}$ (CFU/mL) of each bacteria dilution was counted on the next day (Anderstam et al., 1983). The Colonies Forming Units (CFU) per $\mathrm{mL}$ was calculated as follow:

$$
C=\frac{n}{s x d}
$$

(Equation 1)

Where; $\mathrm{c}=$ concentration, $\mathrm{CFU} / \mathrm{mL} ; \mathrm{n}=$ number of colonies; $\mathrm{d}=$ dilution blank; $\mathrm{s}=$ volume of transferred to plate.

\section{Determining the mutagenicity of bacteria}

The Ames test was carried out to determine the mutagenicity of bacteria after $24 \mathrm{hr}$ of EMR exposure. The treated bacteria were spread on minimal media, which consisted of small amounts of histidine, and the growth of mutant colonies was counted after 2 to 4 days of incubation at $37^{\circ} \mathrm{C}$ (Najafi \& Pezeshki, 2013). Each treatment was replicated to ensure the accuracy of the data. The mutagenicity of bacteria was proportional to the number of colonies observed. According to Vijay et al. (2018), the mutagenicity ratio (MR) of bacteria is calculated as follows:

$$
M R=\frac{S R+I R}{S R} \quad(\text { Equation } 2)
$$


Where, $\mathrm{MR}=$ Mutagenicity ratio; $\mathrm{SR}=$ Spontaneous Revertants; IR = Induced Revertants.

\section{Data analysis}

Data from the experimental results were analyzed using the SPSS Statistics 17.0 software and one-way ANOVA, while significant differences in treatments were determined by using the TukeyKramer procedure.

\section{RESULTS AND DISCUSSION}

\section{Phenotypic identification}

Bacterial strains isolated from the UMT hostel and Lake of UniSZA were identified through phenotypic and molecular identification. Bacterial strains isolated from UMT hostel were labeled as U, whereas strains from the Lake of UniSZA were labeled as T. Table 1 below showed the results of morphology, color, and biochemical characteristics of bacterial species isolated from UMT hostel. Based on Table 1, U2 which was isolated from UMT hostel showed different biochemical characteristics compared to U3 but has similar characteristics with the U1 bacterial strain. Both, the U1 bacterial strain and U2, were Gram-negative bacteria and unable to hydrolyze starch due to a negative response in the amylase test. However, both strains were able to ferment glucose as it revealed a yellow butt color during the TSI test. As for U3, the Gram-positive bacterium had a positive response in the catalase and oxidase tests. U3 was able to ferment glucose and hydrolyze starch. While, T1, T2 and T3 isolates from Lake of UniSZA were Gram-positive bacteria and able to ferment glucose and hydrolase starch. However, T1 showed a negative response to the catalase test, which indicates that it is facultatively anaerobic, and $\mathrm{T} 2$ and $\mathrm{T} 3$ showed a positive response to the catalase test.

\section{Molecular identification of bacteria}

The identification of isolated bacteria was confirmed by molecular methods. The sequence of PCR products was blasted with the database from NCBI. Bacteria isolates from UMT hostel consisted of Enterobacter sp. (U2) and Bacillus toyonensis (U3), which have $97 \%$ and $95 \%$ sequence similarities respectively. However, the U1 bacterial strain was unidentified due to a low percentage of similarity with any sequence in Data Bank recommended that the bacterial isolate $\mathrm{U} 1 \mathrm{might}$ be a new genus or species. On the other hand, the isolated bacteria from Lake of UniSZA consisted of Paenibacillus sp. (T1), B. thuringiensis (T2), and $B$. subtilis (T3) strains. The percentage of identification of these three bacterial species was $97 \%$ for both Paenibacillus sp. and B. subtilis and $98 \%$ for $B$. thuringiensis. Table 2 showed the BLAST results of the isolated bacteria.

\begin{abstract}
Abiotic factors
Abiotic factors such as growth temperature, salinity, and $\mathrm{pH}$, were carried out to determine the optimum range for each isolated bacterium that is required for adaptation to different environmental conditions. Table 3 showed the results of experimental tests on bacterial species isolated from UMT hostel and Lake of UniSZA. The U1 bacterial strain, Enterobacter sp., B. thuringiensis, and $B$. subtilis were able to grow in temperatures ranging between $25^{\circ} \mathrm{C}$ to $50^{\circ} \mathrm{C}$. However, B. toyonensis and Paenibacillus sp. were unable to survive at a temperature of $50^{\circ} \mathrm{C}$. The optimum growth temperature for both species lay between $25^{\circ} \mathrm{C}$ to $45^{\circ} \mathrm{C}$. Based on Table 3 above, the NA media plate containing $7.5 \% \mathrm{NaCl}$ can inhibit the growth of $\mathrm{U} 1$ bacterial strain, B. toyonensis, and Paenibacillus sp. compared to the other three bacterial species. Enterobacter sp., B. thuringiensis, and B. subtilis can survive at a high concentration of salt but do
\end{abstract}

Table 1. Morphology, color, and biochemical characteristics of bacteria isolated from UMT hostel and Lake of UniSZA

\begin{tabular}{|c|c|c|c|c|c|c|}
\hline Bacteria & U1 & U2 & U3 & T1 & $\mathrm{T} 2$ & T3 \\
\hline Colony morphology & Round & $\begin{array}{l}\text { Smooth and } \\
\text { round }\end{array}$ & $\begin{array}{l}\text { Irregular } \\
\text { and big }\end{array}$ & $\begin{array}{l}\text { Punctiform with } \\
\text { entire edges }\end{array}$ & $\begin{array}{l}\text { Round with } \\
\text { wrinkled }\end{array}$ & $\begin{array}{l}\text { Irregular with } \\
\text { lobate margin }\end{array}$ \\
\hline Color & Milky white & Yellow & Milky white & Milky white & Yellow & Milky white \\
\hline Gram stains & - & - & + & + & + & + \\
\hline Catalase & + & + & + & - & + & + \\
\hline Oxidase & - & - & + & + & - & + \\
\hline Amylase & - & - & + & + & + & + \\
\hline Fermentation of glucose & + & + & + & + & + & + \\
\hline Indole production & - & - & - & - & - & - \\
\hline
\end{tabular}

+ Positive, - Negative. 
Table 2. Result BLAST of bacteria isolated from UMT hostel and Lake of UniSZA

\begin{tabular}{ccc}
\hline Bacteria strains & Identity $(\%)$ & Bacteria genus/species \\
\hline U1 & 85 & Unidentified \\
U2 & 97 & Enterobacter sp. \\
U3 & 95 & Bacillus toyonensis \\
T1 & 97 & Paenibacillus sp. \\
T2 & 98 & B. thuringiensis \\
T3 & 97 & B. subtilis \\
\hline
\end{tabular}

Table 3. Experimental tests for abiotic factors on bacterial species

\begin{tabular}{lccc}
\hline Bacteria sp. & $\begin{array}{c}\text { Growth } \\
\text { Temperature }\left({ }^{\circ} \mathrm{C}\right)\end{array}$ & $\begin{array}{c}\text { Salinity tolerance } \\
(\% \mathrm{NaCl} \text { in NA media })\end{array}$ & $\begin{array}{c}\mathrm{pH} \\
\text { tolerance }\end{array}$ \\
\hline U1 strain & $25-50$ & $0-5.0$ & $5-9$ \\
Enterobacter sp. & $25-50$ & $0-7.5$ & $4-9$ \\
B. toyonensis & $25-45$ & $0-5$ & $5-9$ \\
Paenibacillus sp. & $25-45$ & $0-5$ & $5-9$ \\
B. thuringiensis & $25-50$ & $0-7.5$ & $5-9$ \\
B. subtilis & $25-50$ & $0-7.5$ & $5-9$ \\
\hline
\end{tabular}

not require it for growth (Pepper et al., 2015). As for the $\mathrm{pH}$ tolerance range, most of the isolated bacteria were able to survive in $\mathrm{pH}$ that ranged from 5.0 to 9.0 except Enterobacter sp., which was able to survive in an acidic environment of $\mathrm{pH} 4.0$. According to Kus (2014), the Enterobacter sp. can inhabit inside the human intestinal tract, hence, allowing it to adapt in an acidic environment.

\section{Viability of isolated bacteria}

The bacterial isolates were exposed to two different EMR frequencies (10 MHz and $5 \mathrm{GHz}$ ) for screening the viability of high ambient EMR bacteria. The non-exposed specimen acted as a negative control when comparing significant differences between the treated and non-treated bacteria. Based on Figure 1, the viability of the U1 bacterial strain showed no significant difference $(p>0.05)$ after $10 \mathrm{MHz}$ and $5 \mathrm{GHz}$ exposure. However, the U1 bacterial strain had increased in viability after exposure to $5 \mathrm{GHz}$ but exhibited constant viability after exposure to $10 \mathrm{MHz}$. The viability of Enterobacter sp. and Paenibacillus sp. showed a significant increase after $24 \mathrm{hr}$ of exposure to both EMR frequencies of $10 \mathrm{MHz}$ and $5 \mathrm{GHz}$. Conversely, the viability of $B$. toyonensis and $B$. subtilis had decreased after $24 \mathrm{hr}$ of exposure to $5 \mathrm{GHz}$. On the other hand, the viability of $B$. thuringiensis increased after $24 \mathrm{hr}$ of exposure to $5 \mathrm{GHz}$. The decrease in the viability of bacteria might due to the DNA damage caused by the interaction between the bacterial membrane and the electric field (Nweze, 2009). While, according to
Kalalou et al. (2010), an increase in the viability of bacteria due to the electric field can stimulate and accelerate the entry of glucose into the bacterial membrane.

\section{Mutagenicity of isolated bacteria}

The six isolated bacteria were exposed to different EMR frequencies to produce induced revertants in minimal media. The non-exposed control acted as a negative control to obtain spontaneous revertants of bacteria in minimal media. Table 4 shows the mutagenicity ratio of each bacterial species isolated from both UMT hostel and the Lake of UniSZA, Gong Badak. The exposure to a frequency of $5 \mathrm{GHz}$ had given rise to mutagenicity in all bacterial species except Enterobacter sp., which exhibited non-mutagenic upon exposure to both EMR frequencies which indicates that it is resistant to high EMR exposure. However, the U1 bacterial strain and $B$. subtilis had shown nonmutagenic capabilities after exposed to $10 \mathrm{MHz}$, but mutagenic upon $5 \mathrm{GHz}$ exposure. While, $B$. toyonensis, B. thuringiensis, and Paenibacillus sp. were mutagenic after exposed as low as $10 \mathrm{MHz}$ EMR. As a result, EMR frequency has the potential to efficiently induce mutagenicity in bacteria depends on the species of the bacteria. The Enterobacter sp. colony had expanded when growing in minimal media upon EMR exposure due to biofilm formation, as shown in Figure 2. During biofilm formation, numerous bacterial species were able to communicate with one another through a mechanism called quorum sensing (Naves 


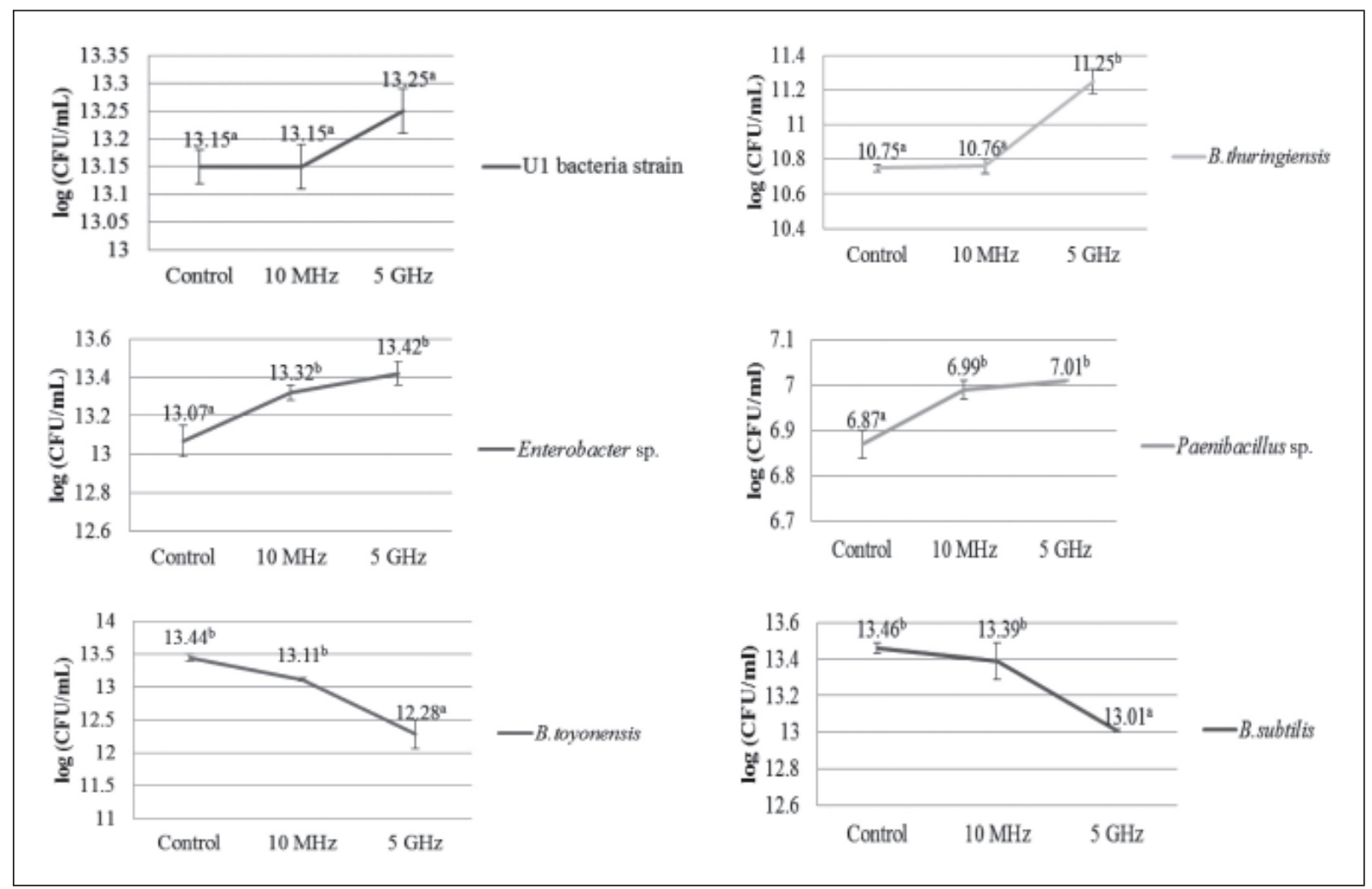

Fig. 1. Viability of isolated bacterium from UMT hostel and Lake of UniSZA after $24 \mathrm{hr}$ of exposure to different EMR frequencies. Data are expressed as mean \pm S.D. of replicate samples.

Table 4. Mutagenicity ratio of bacteria after $24 \mathrm{hr}$ exposure to $10 \mathrm{MHz}$ and $5 \mathrm{GHz}$

\begin{tabular}{lcc}
\hline Bacteria & $\begin{array}{c}\text { Mutagenicity ratio } \\
\text { (After 24 } \mathrm{hr} \text { exposure to 10 MHz) }\end{array}$ & $\begin{array}{c}\text { Mutagenicity ratio } \\
\text { (After 24 hr exposure to 5 GHz) }\end{array}$ \\
\hline U1 strain & Non-mutagenic & Mutagenic \\
Enterobacter $\mathrm{sp}$. & Non-mutagenic & Non-mutagenic \\
B. toyonensis & Mutagenic & Mutagenic \\
Paenibacillus $\mathrm{sp}$. & Mutagenic & Mutagenic \\
B. thuringiensis & Mutagenic & Mutagenic \\
B. subtilis & Non-mutagenic & Mutagenic \\
\hline
\end{tabular}

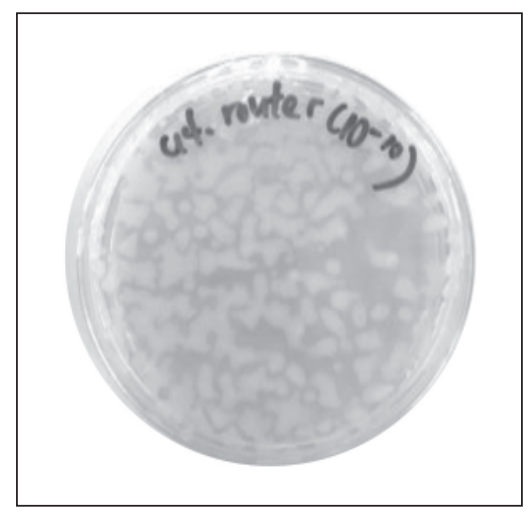

Fig. 2. Expansion of the Enterobacter sp. colony upon $5 \mathrm{GHz}$ EMR exposure. et al., 2010). According to Laura Estela and Ramos (2012), these bacteria can produce secondary metabolites to function as signaling molecules, thus, enhancing the biofilm formation process. Biofilms can develop bacterial subpopulation by switching to the quiescent state to form a smallcolony known as small colony variants ( $\mathrm{SCVs}$ ), which can lead to increased adherence, autoaggregation, increased hydrophobicity, and lowlevel motility (Jamal et al., 2015). Therefore, biofilm formation of Enterobacter sp. can withstand a wide range of harsh environmentally stressful conditions and act as a survival mechanism in high EMR field conditions. 


\section{CONCLUSION}

In conclusion, six species of bacteria, which were isolated from both UMT hostel and the Lake of UniSZA in Gong Badak, were successfully identified and characterized except U1 bacterial strain could not be identified. In the viability and mutagenicity tests, Enterobacter sp., which was isolated from UMT hostel, showed increased viability and nonmutagenic after $24 \mathrm{hr}$ of exposure to both EMR frequencies of $10 \mathrm{MHz}$ and $5 \mathrm{GHz}$, whereas the other five bacterial species exhibited mutagenic capabilities. Enterobacter sp., which inhabits an area in UMT hostel that had a strong electric field $(0.014 \mathrm{~V} / \mathrm{M})$, was able to form a biofilm in response to high ambient EMR. Since the biofilm formed by Enterobacter sp. is resistant to high ambient EMR; hence, the biofilm's role when exposed to high EMR should be studied to understand multiple microbial population interactions in harsh environments. Also, further studies on this bacterium should be carried out for designing bacterial bioremediation to high ambient EMR.

\section{ACKNOWLEDGEMENTS}

The authors wish to express their gratitude to the laboratory staff at the Faculty of Bioresources and Food Industry of Universiti Sultan Zainal Abidin (UniSZA) Besut Campus, East Coast Environmental Research Institute, UniSZA, and Universiti Malaysia Terengganu (UMT) for their invaluable assistance and hospitability throughout the study. Thanks to DNZ Teknik Enterprise for providing the DDS VFO Signal Generator. This research was supported by the Fundamental Research Grant Scheme FRGS/1/2015/ SG02/UNISZA/02/1/1(155).

\section{REFERENCES}

Altschul, S.F., Gish, W., Miller, W., Myers, E.W. \& Lipman, D.J. 1990. Basic local alignment search tool. Journal of Molecular Biology, 215(3): 403-410.

Anderstam, B., Hamnerius, Y., Hussain, S. \& Ehrenberg, L. 1983. Studies of possible genetic effects in bacteria of high-frequency electromagnetic fields. Hereditas, 98(1): 11-32.

Bahaodini, A., Owjfard, M., Tamadon, A. \& Jafari, S.M. 2015. Low-frequency electromagnetic fields long-term exposure effects on testicular histology, sperm quality, and testosterone levels of male rats. Asian Pacific Journal of Reproduction, 4(3): 195-200.
Cam, S.T., Seyhan, N., Kavaklı, C. \& Çelikbıçak, Ö. 2014. Effects of $900 \mathrm{MHz}$ radiofrequency radiation on skin hydroxyproline contents. Cell Biochemistry and Biophysics, 70(1): 643-649.

Cmara, P. 2014. Effect of exposure to non-ionizing radiation (electromagnetic fields) on human system: a literature review. Journal of Interdisciplinary Histopathology, 2(4): 187.

Estela, C.R.L. \& Alejandro, P.R. 2012. Biofilms: a survival and resistance mechanism of microorganisms. In: Antibiotic-Resistant Bacteria. M. Pana (Ed.). IntechOpen. pp. 159-178.

Hasshim, N.S., Umar, R., Sabri, N.H., Rosley, K.A., Tukimin, R. \& Parthasarathy, S.R. 2019. Spatial model of non-ionizing radiation exposure around gong badak. Indian Journal of Public Health Research \& Development, 10(4): 811816.

Hemraj, V., Diksha, S. \& Avneet, G. 2013. A Review on commonly used biochemical test for bacteria. Innovare Journal of Life Sciences, 1(1): 1-7.

Hidisoglu, E., Kantar Gok, D., Er, H., Akpinar, D., Uysal, F., Akkoyunlu, G., Ozen, S., Agar, A., Yargicoglu, P. 2016. 2100-MHz electromagnetic fields have different effects on visual evoked potentials and oxidant/antioxidant status depending on exposure duration. Brain Research, 1635: 1-11.

Jamal, M., Tasneem, U., Hussain, T. \& Andleeb, S. 2015. Bacterial Biofilm: Its composition, formation, and role in human infectious. Journal of Microbiology and Biotechnology, 4(3): 15.

Kalalou, I., Zerdani, I. \& Faid, M. 2010. Antagonistic action of bio preservative Lactobacillus plantarum strain on pathogenic E. coli $\mathrm{O} 157: \mathrm{H} 7$ in fresh camel meat stored at $10^{\circ} \mathrm{C}$. World Journal of Dairy \& Food Science, 5(1): 07-13.

Kus, J.V. 2014. Infections due to Citrobacter and Enterobacter. Reference Module in Biomedical Sciences. Elsevier.

Lerchl, A., Klose, M., Grote, K., Wilhelm, A.F.X., Spathmann, O., Fiedler, T., Streckert, J., Hansen, V. \& Clemens, M. 2015. Tumor promotion by exposure to radiofrequency electromagnetic fields below exposure limits for humans. Biochemical and Biophysical Research Communications, 459(4): 585-590.

Li, M., Qu, J.H. \& Peng, Y.Z. 2004. Sterilization of escherichia coli cells by the application of pulsed magnetic field. Journal of Environmental Sciences, 16(2): 348-352.

Martens, A.L., Bolte, J.F.B., Beekhuizen, J., Kromhout, H., Smid, T. \& Vermeulen, R.C.H. 2015. The validity of at-home model predictions as a proxy for personal exposure to radiofrequency electromagnetic fields from mobile phone base stations. Environmental Research, 142: 221-226. 
Mohamed, A.A., Ali, F.M., Gaafar, E.A. \& Magda, H.R. 1997. Effects of magnetic field on the biophysical, biochemical properties, and biological activity of Salmonella typhi (Master). Cairo University, Egypt.

Najafi, M.B.H. \& Pezeshki, P. 2013. Bacterial Mutation: Types, mechanisms, and mutant detection methods: a review. European Scientific Journal, 4: 628-638.

Naves, P., del Prado, G., Huelves, L., RodríguezCerrato, V., Ruiz, V., Ponte, M.C. \& Soriano, F. 2010. Effects of human serum albumin, ibuprofen, and N-acetyl-1-cysteine against biofilm formation by pathogenic Escherichia coli strains. Journal of Hospital Infection, 76(2): 165-170.

Nweze, E.I. 2009. Virulence properties of diarrheagenic E. coli and etiology of diarrhea in infants, young children, and other age groups in Southeast, Nigeria. American-Eurasian Journal of Scientific Research, 4(3): 173-179.

Rosley, K.A., Sabri, N.H., Hasshim, N.S., Umar, R., Tukimin, R. \& Parthasarathy, S.R. 2019. Nonionizing radiation measurement around four different selected areas. Indian Journal of Public Health Research \& Development, 10(4): 829-833.
Salmen, S.H., Alharbi, S.A., Faden, A.A. \& Wainwright, M. 2018. Evaluation of the effect of the high-frequency electromagnetic field on growth and antibiotic sensitivity of bacteria. Saudi Journal of Biological Sciences, 25(1): 105-110.

Syafiqah, H.N., Hazmin, S.N., Umar, R., Dianah, A.R.S.N., Jaafar, H., Kamarudin, M.K.A., Dagang, A.N. \& Ilyas, A.I.A. Non-ionizing radiation: exposure level at UMT and UniSZA campus. ASM Science Journal, Special Issue 2018(1): 183-194.

Syaza, S.K.F., Umar, R., Hazmin, S.N., Kamarudin, M.K.A., Hassan, A. \& Juahir, H. 2017. Nonionizing radiation as threat in daily life. Journal of Fundamental and Applied Sciences, 9(2S): 308-316.

Tadevosyan, H., Kalantaryan, V. \& Trchounian, A. 2008. Extremely high-frequency electromagnetic radiation enforces bacterial effects of inhibitors and antibiotics. Cell Biochemistry and Biophysics, 51(2-3): 97-103.

Vijay, U., Gupta, S., Mathur, P., Suravajhala, P. \& Bhatnagar, P. 2018. Microbial mutagenicity assay: ames test. Bio-protocol, 8(6): e2763. 